\title{
DOS NUEVAS OBRAS DEL PINTOR NOVOHISPANO ANTONIO DE TORRES (1667-1731): EL SANTO ECCE HOMO DEL PORTAL DEL CONVENTO DE LA ENCARNACIÓN DE GRANADA Y LA DORMICIÓN DE LA VIRGEN DEL SEMINARIO DE SACERDOTES OPERARIOS DIOCESANOS DE CIUDAD DE MÉXICO
}

TWO NEW WORKS BY THE NOVOHISPANIC PAINTER ANTONIO DE TORRES (1667-1731): THE HOLY ECCE HOMO AT THE PORTAL OF THE CONVENT OF THE INCARNATION IN GRANADA AND THE DORMITION OF THE VIRGIN AT THE SEMINAR OF DIOCESAN OPERATORS PRIESTS IN MEXICO CITY

\author{
LÁzaro Gila Medina \\ Universidad de Granada. España \\ ORCID: 0000-0001-8797-1739 \\ lgila@ugr.es
}

\begin{abstract}
Este trabajo tiene como fin dar a conocer dos nuevas pinturas de Antonio de Torres (1667-1731): una consagrada al desaparecido Santo Ecce Homo del Portal de Mercaderes de la Plaza Mayor -hoy Zócalo- de Ciudad de México, localizada en el convento de la Encarnación de Granada, y la segunda dedicada a la Dormición de la Virgen del Seminario de Sacerdotes Operarios Diocesanos en aquella gran metrópoli, firmadas y fechadas, respectivamente, en 1726 y 1713. Mas, como preámbulo, ofrecemos un resumen histórico-artístico de dicho convento y un apunte biográfico del artista.

Palabras claves: pintura barroca; Antonio de Torres; siglos XVII y XVIII; Ciudad de México; Granada (España).
\end{abstract}


This paper has the aim to introduce two new paintings by Antonio de Torres (1667-1731): the first one dedicated to the Holy Ecce Homo, formerly at Portal de Mercaderes of the Main Square -today Zocalo Square- in Mexico City and finally located at the Convent of Incarnation in Granada. The second one is dedicated to the Dormition of the Virgin at the Seminar of the Diocesan Operators Priests in that great city. They are signed and dated respectively in 1726 and 1713. Further, as a preamble, we will offer a historic-artistic resume of such convent and a biographic note of the artist. (Spain).

Keywords: Baroque painting; Antonio de Torres; $17^{\text {th }}$ and $18^{\text {th }}$ centuries; México City; Granada

\section{INTRODUCCIÓN}

Hace cuatro años, en la revista del Museo de América, di a la luz un artículo dando a conocer una serie inédita mariana de este pintor novohispano, aún poco valorado ${ }^{1}$. Son siete pinturas dedicadas a momentos principales de la vida de María, más una octava con la Virgen de Guadalupe. Todas ellas se hallan dispersas por distintas dependencias del monasterio de clarisas franciscanas de la Encarnación en Granada y, según la tradición oral de la comunidad de religiosas, llegaron con la dote de una novicia al entrar en el mismo.

No obstante, previo al estudio de la serie, ofrecimos una novedosa biografía de Antonio de Torres, bien a partir de noticias ya conocidas, aunque dispersas en revistas, algunas de difícil acceso, junto a otros nuevos datos fruto de mis investigaciones. Finalmente, pensamos oportuno concluirlo incluyendo dos excelentes pinturas de Antonio de Torres, ya publicadas, pero sin acertar en sus verdaderas iconografías. Existentes en el convento de carmelitas descalzas de Antequera (Málaga), fueron mostradas una como un Nazareno en una de sus caídas en su camino al Calvario y la otra como la Asunción o la Virgen de los Remedios ${ }^{2}$, cuando se trata de dos curiosos trampantojos o "copias a lo divino" en palabras de Alfonso E. Pérez Sánchez ${ }^{3}$ de devociones novohispanas que antaño gozaron de gran arraigo popular. Así, el Nazareno representa al Jesús Caído del Hospital de su nombre y de la Limpia Concepción, fundación de Hernán Cortés (1485-1547), mientras el segundo representa a Nuestra Señora de la Redonda, ambas esculturas muy veneradas y queridas hasta la actualidad en Ciudad de México.

Recientemente, en una somera limpieza de un gran lienzo de la clausura conventual granadina, ha aparecido la firma de Antonio de Torres y la fecha 1726. Es decir, fue pintado el mismo año que la serie mariana -la Guadalupana

${ }^{1}$ Gila Medina, 2015: 82-113.

${ }^{2}$ Romero Benítez, 1989: 105-106; 2012: 112 y 114. Aunque, en verdad, el primero en dar a conocer estos dos cuadros, aunque sin identificar su verdadera iconografía, fue Clavijo García, 1984: 98-99.

${ }^{3}$ Pérez Sánchez, 1992: 139-155. 
es de $1724^{4}$-. En consecuencia, todas estas pinturas, fruto del mismo encargo y comitente, entran en su segunda y última etapa profesional que va desde 1724 al 1731 en que falleció -en 1722 su salud sufrió un gran deterioro que superó; al año siguiente falleció su mujer Inés de Córdoba, casó de nuevo en 1724 y falleció siete años después-.

Es un espléndido cuadro conocido por las religiosas como un Ecce Homo, aunque el tema es mucho más complejo y no nos ha sido fácil desentrañarlo. Pues, en realidad, se trata de una copia de otra devoción novohispana, ahora una imagen en pintura, que fue objeto de una gran devoción popular hasta finales del siglo XIX en la capital del virreinato. En definitiva, del Santo Ecce Homo del Portal, pues la pintura original recibía culto hasta finales del siglo XIX en un nicho u hornacina situada en el Portal de Mercaderes de la Plaza Mayor-ocupaba parte del lado oeste de la misma-.

Mas, como anticipamos, con este artículo no solo damos a conocer esta copia de tan venerada imagen mexicana, que enriquece el ya de por sí rico conjunto de pinturas de Antonio de Torres de este monasterio granadino, siendo además, lo que creemos muy significativo, el único caso de esta advocación mexicana documentado en la Península hasta la fecha, sino que a la par presentamos un excelente cuadro inédito de la Dormición de la Virgen de la comunidad de Sacerdotes Operarios Diocesanos de Ciudad de México. De hermosas proporciones $140 \mathrm{x}$ $190 \mathrm{~cm}$, está firmado también por Antonio de Torres y fechado en 1713; en consecuencia, corresponde a su primera etapa laboral.

\section{APROXIMACIÓN HISTÓRICO-ARTÍSTICA AL CONVENTO DE LA ENCARNACIÓN DE GRANADA Y A LA BIOGRAFÍA DEL PINTOR ANTONIO DE TORRES}

Como ambos aspectos ya antes los afrontamos en detalle, ahora solo marcaremos aquellos hitos históricos claves, tanto del convento como de la biografía del artista.

Los orígenes del monasterio se remontan a 1524, cuando doña Inés de Arias funda en su casa del barrio de San Matías un beaterio bajo la regla de Santa Clara $^{5}$, origen del actual convento. En 1541, el arzobispo de Granada don Gaspar de Ávalos (1485-1545), ya electo de Santiago de Compostela ${ }^{6}$, confió a las clarisas de San Antonio de Baeza, bajo la dirección de sor Isabel de la Cruz, su hermana,

${ }^{4}$ Barea Azcón, 2007: 317-332. Esta autora dio a conocer la Virgen de Guadalupe, aunque no se dio cuenta que junto a ella se hallaban varios cuadros de la serie mariana que publicamos en 2015.

5 Gómez-Moreno González, 1892: 382.

${ }^{6}$ López Rodríguez, 1993: 54-67. 
venir a Granada a refundar en unas casas de la calle San Jerónimo ${ }^{7}$. Esta gran arteria urbana, cuyo hito esencial era la parroquia de los Santos Justo y Pastor, era un eje cardinal en la Granada Moderna al unir la catedral con el monasterio de San Jerónimo, por lo que en ese entorno fundaron importantes órdenes religiosas y se instalaron algunas familias castellanas y genovesas.

El traslado tuvo lugar en 1542, concretamente a unas casas paredañas al templo parroquial, cuyo clero aceptó que las religiosas utilizaran su iglesia para sus necesidades cultuales -fue tal la integración que pronto la parroquia fue conocida también como de la Encarnación-. Por lo que los esfuerzos edilicios de las monjas se centraron en la construcción de un gran claustro, muy bien conservado, como elemento o módulo aglutinador para las diferentes partes que integran el convento. Realizado en el último tercio del XVI, es un patio rectangular rodeado de galerías superpuestas de arcos de medio punto, si bien el lado sur se corona con un tercer piso a modo de solarium -recordemos que parte de la muralla islámica de la ciudad (un paño de $25 \mathrm{~m}$ de longitud y $4 \mathrm{~m}$ de ancho), fechable en los siglos XI y XII ${ }^{8}$, quedó dentro del conjunto conventual-.

En 1799, a los 32 años de la expulsión de la Compañía de Jesús (1767), la parroquia de los Santos Justo y Pastor se trasladó a la vecina iglesia del ex colegio de San Pablo, más amplia y mejor amueblada, quedando el viejo templo parroquial para uso exclusivo de las religiosas. Aunque no lo gozarían muchos años, pues, en 1835, tras la Desamortización de Mendizábal, que puso en venta todo el conjunto conventual, lo compró un particular para demolerlo y construir viviendas. Por fortuna, la piqueta tan solo se llevó por delante la antigua iglesia parroquial, ya que, por razones aún no bien conocidas, el derribo fue paralizado cuando solo quedaba en pie una nave lateral, que luego se incorporaría al conjunto conventual que sí se conservó integro. La propiedad pasó por varias manos hasta recaer de nuevo en las religiosas, quienes efectuaron varias obras para adecentar y unificar las fachadas y tiempo después, en 1902, una capilla muy sencilla, pero a su vez funcional en la crujía oriental del claustro, lindera con la calle Niños Luchando, a su vez paralela a la transitada calle de San Jerónimo9.

Por lo que atañe a Antonio de Torres, comenzamos advirtiendo que la historiografía novohispana, tanto la mexicana como la foránea, ni ha sido abundante, ni objetiva y justa con él. Así, con anterioridad a nuestro artículo de 2015, cuatro son los principales estudiosos que, sucesivamente, se han ocupado de él: Manuel Toussaint $^{10}$, Mina Ramírez Montes ${ }^{11}$, José Rogelio Ruiz Gomar ${ }^{12}$ y Guillermo

\footnotetext{
${ }^{7}$ Chica Benavides, 1764: s. p.

8 Álvarez García, 2009: 1403-1414.

9 Barrios Rozúa, 1998: 379-381.

${ }_{10}$ Toussaint, 1990: 154-156.

${ }^{11}$ Ramírez Montes, 1988: 265-272.

12 Ruiz Gomar, 1989: 222-224.
} 
Tovar de Teresa ${ }^{13}$. En consecuencia, necesita una monografía de conjunto, lo que sí se está haciendo con otros artistas; además, para enredar aún más las cosas, existe otro pintor también llamado Antonio de Torres, es decir, un homónimo, trabajando casi por las mismas fechas en el arte de la pintura.

Antonio de Torres, bautizado el 13 de abril de 1667 en el Sagrario catedralicio de Ciudad de México -su partida de bautismo fue dada a conocer por José Rogelio Ruiz Gomar ${ }^{14}$-, fue el cuarto hijo del matrimonio formado por Tomás de Torres y Lorenzana y María Beltrán de los Reyes -algunos de sus estudiosos creen que nació en 1666, es decir un año antes, estando el origen de este pequeño error en Francisco de la Maza-. Especial interés ofrece su madre, la primogénita de Sebastián Rodríguez, de origen español, y de Isabel Beltrán de los Reyes. Desposados en México, en enero de 1636, la pareja tuvo otros tres hijos más: Antonio, Catalina y Josefa, siguiendo un orden cronológico. El mayor Antonio Rodríguez (hacia 1635-finales del siglo XVII) casaría en 1659 con Antonia Juárez, hija del célebre pintor José Juárez (hacia 1617-hacia 1670), en cuyo taller se formó - de nuevo se da el hecho de que el aprendiz case con la hija del maestro-. El afamado pintor Antonio Rodríguez ${ }^{15}$, activo en la segunda mitad del Seiscientos, fue continuado en su arte por sus hijos, Nicolás (1667-1734) y Juan Rodríguez Juárez (1675-1728), primos-hermanos de Antonio de Torres -Nicolás fue bautizado en enero de $1667^{16}$, por lo que sería unos meses mayor que él, que, como hemos visto, lo fue en abril-.

Estos lazos familiares de Antonio de Torres con su tío el pintor Antonio Rodríguez avalan que fuera su maestro, compartiendo en el taller las enseñanzas con sus primos, Nicolás, Juan y otros aprendices. Pero no olvidemos que en el horizonte artístico mexicano del momento hubo otros afamados pintores del pleno barroco, como Cristóbal de Villalpando (hacia 1649-1714), Juan Correa (16461716), Juan Sánchez Salmerón (activo entre 1661 y 1697), etc., contemporáneos de nuestro artista, aunque no coetáneos, pues eran de una generación anterior. Precisamente, Antonio de Torres formaría parte de esa siguiente generación de pintores considerada, injustamente, como secundaria, aunque debió ser clave al servir de puente entre estos maestros del pleno barroco y la siguiente generación, ya del barroco final, donde incluimos a José de Ibarra (1685-1756), Miguel Cabrera (1695-1768) o a José de Páez (1720-1790) -sería Manuel Toussaint quien, en 1965, a esta generación puente la denominó "pintores secundarios, anteriores a Ibarra y Cabrera”, incluyendo una amplia nómina de artistas, aunque

\footnotetext{
13 Tovar de Teresa, 1997: 340.

${ }_{14}$ Ruiz Gomar, 1989: 238.

15 Ruiz Gomar, 1983: 25-36.

16 Ruiz Gomar, 1989: 233.
} 
resaltaba a Antonio de Torres, a quien calificó como "el más destacable pintor de este grupo"17-.

Obviando otros detalles, lo cierto es que Antonio de Torres para 1686, con 19 años, al otorgar la dote a Inés de Córdoba, su futura esposa, ya aparecía como oficial de pintor $^{18}$. Se casaron en septiembre de ese año, naciendo solo Inés Josefa de Torres, que fue bautizada en el Sagrario catedralicio y casó, en 1709, con Pedro de Zúñiga, viudo ${ }^{19}$.

En 1697, con 30 años, ya era maestro de pintor ${ }^{20}$ con taller, con oficiales y aprendices, siendo requerido para realizar diversas tasaciones y valoraciones de pinturas, lo que testimonia el prestigio socio-laboral ya alcanzado. Llegaba a su madurez y plenitud profesional, laborando para numerosos lugares de México, especialmente para la metrópoli. Además, los encargos no solo eran pinturas, sino que también su complejo obrador estaría preparado para afrontar tareas colaterales a las pictóricas, como se deduce de su inventario post mortem de 1731, donde figuran imágenes en blanco, es decir, talladas, pero sin policromar, así como algún retablo y piezas de otros para dorar ${ }^{21}$.

Las dos primeras décadas del Setecientos debieron ser su época de total grandeza y fecunda laboriosidad profesional, lo que le afectaría a la salud, hasta el punto que, el 13 de octubre de 1722, otorgaba testamento, nombrando por heredera a Inés Josefa, hija única, y como uno de sus albaceas a su primo-hermano Juan Rodríguez Juárez. No obstante, el reducir su ritmo de trabajo le permitió recobrar la salud, aunque, por otro lado, sufrió un gran revés en lo personal, pues al año siguiente, en 1723, enviudó, casando en 1724 con María Millán, sin tener descendencia. Ahora arranca su segundo periodo profesional, también de gran dedicación y al que pertenecen todos los cuadros granadinos. Etapa que concluiría antes de agosto de 1731, pues el día 6, María Millán, su viuda, realizó el inventario post mortem de sus bienes, dándoselos a Inés Josefa de Torres, su hija y heredera, viuda de Pedro de Zúñiga ${ }^{22}$.

17 Toussaint, 1990: 149-156.

18 Tovar de Teresa, 1997: 340. Si bien debemos hacer notar que sitúa su fecha de nacimiento en 1666, es decir, mantiene el error que arranca de Francisco de la Maza, precisamente el maestro de Guillermo Tovar. Igualmente afirma que su nombre es Inés López de Córdoba.

19 Ruiz Gomar, 1989: 235.

${ }^{20}$ Tovar de Teresa, 1997: 340.

${ }^{21}$ A título de ejemplo señalamos: unos santos de bulto, como un San Francisco grande, unos cristos en blanco, etc. Para más información véase el artículo citado de Ramírez Montes, 1988: 265-272. El título del artículo "Testamento del pintor Antonio de Torres" se queda corto con relación a la realidad, pues su autora no solamente da a conocer su testamento o la última voluntad del artista, de fecha 13 de octubre de 1722, sino que también publica el inventario post mortem del pintor, muy rico en información.

${ }^{22}$ Ramírez Montes, 1988: 270-272. 
Este boceto biográfico se debería completar señalando aquellos encargos más importantes que afrontó en los casi 40 años de actividad. En verdad, salvo la obra de Granada, al menos, han sido citados por otros estudiosos, en los medios y lugares más dispares, mas, como ya los recogimos en 2015, ahora no insistiremos en ello. Solo señalar que, en esencia, le llegaron de las órdenes religiosas más importantes y con mayor presencia en el territorio novohispano, destacando por su envergadura los encargos provenientes de los franciscanos, los filipenses y los jesuitas. Para los primeros fue su pintor predilecto, confiándole grandes ciclos tanto para el convento, Casa Grande, de Ciudad de México como para San Luis Potosí y muy especialmente para la fundación vinculada a la Propaganda Fide de Guadalupe-Zacatecas, en el Camino Real de Tierra Adentro. Para aquí pintaría una serie mariana con 16 lienzos, de mediano formato, otros tres grandes para la sacristía, otros más de tema bíblico -hoy todos en el museo, excepto los tres de la sacristía-, incluso otros, a modo de retratos, de los Padres de la Iglesia ${ }^{23}$.

Especial significación, por su originalidad, tiene este último género, pues los franciscanos capitalinos le confiaron cuatro originales pinturas -se conservan tres en el Museo Nacional de Historia de Ciudad de México-donde por parejas Antonio de Torres recordaría a algunos de los principales miembros de la orden franciscana que destacaron en los primeros momentos del periodo hispánico. Con ellos se pretendía, como ya era norma desde comienzos del Setecientos para otras corporaciones, ir creando una galería de retratos de hijos ilustres mexicanos. Figuras señeras, en su mayoría oriundos de la Península, pero que habían dedicado lo mejor de su labor profesional a aquellos territorios y a sus gentes, siendo pues la base y fundamento de la identidad mexicana.

A la par también recibiría otros muchos compromisos de particulares, del más dispar origen o lugar y grupo social. Aquí estarían algunos funcionarios de la administración oficial del virreinato, quienes, tras dejar sus cargos, regresaban a la metrópoli con todos sus enseres y bienes muebles. Sin duda, dentro de este último grupo estaría el anónimo granadino que dotó a su hija al ingresar en el monasterio de la Encarnación con nueve lienzos -la Virgen de Guadalupe, la serie mariana y, el último, el Santo Ecce Homo del Portal-. Además, por fortuna, cada vez es más frecuente la aparición de nuevas pinturas en templos, colecciones privadas o fondos de museos, tanto allende como aquende el Atlántico. En la actualidad, las artes plásticas del periodo novohispano, sobre todo la pintura, son objeto de estudio de nuevos historiadores del arte tanto españoles como mexicanos. A la par, y en parte como consecuencia de ello, está siendo muy solicitada por coleccionistas particulares y por museos de muy distinta procedencia geográfica, destacando los estadounidenses y mexicanos. Esta buena aceptación y demanda de obras de este origen ha ocasionado un incremento de sus valoraciones

${ }^{23}$ Sescosse, 1993: 88-92. 
económicas, en algunos casos excesivas y poco reales, pero, en fin, el mercado del arte se mueve por otros parámetros difícil de predecir y evaluar.

Para completar este apunte biográfico, diremos que, por lo que vamos conociendo de Antonio de Torres y ya es bastante, como pintor se nos muestra como un artista que compone con gusto y naturalidad, normalmente teniendo como fuente de inspiración estampas italianas y sobre todo flamencas, a las que llega, bien directamente, pues fueron numerosas las colecciones que alcanzaron gran difusión en aquellos territorios, pensemos por ejemplo en las de Lucas van Leyden (1494-1533), Martín de Vos (1532-1603), Gingio Ghesi (1520-1582), Hendrick Goltzius (1558-1617), Jan P. Saenredam (1565-1607), etc., o a través de la contemplación de pinturas de artistas mexicanos coetáneos y previos a él. En cuanto al color su gama no es muy amplia, pero sí la combina y matiza con gran maestría y delicadeza, destacando sus primorosas y delicadas transparencias, al igual que cuida con enorme esmero todos los detalles de la obra, especialmente las figuras humanas y sus vestiduras, los fondos y las perspectivas, por lo que debe, insistimos en ello, ocupar un puesto significativo en esa generación puente de pintores, activos entre el pleno barroco del Seiscientos y el final o triunfal del Setecientos.

\section{EL SANTO ECCE HOMO DEL PORTAL DEL CONVENTO DE LA ENCARNACIÓN DE GRANADA: CONSIDERACIONES PREVIAS EN TORNO AL DESAPARECIDO ORIGINAL MEXICANO}

No ha sido fácil llegar a identificar qué imagen concreta de Cristo representa este lienzo granadino, firmado y fechado por Antonio de Torres. Esta búsqueda de la imagen originaria y matriz se veía obstaculizada porque, cuando por fin logramos localizarla, nos dimos cuenta de que ya no existe, por lo que aquella gran fama, devoción y fervor popular que concitó antaño se ha ido diluyendo con el tiempo hasta quedar olvidada de la memoria colectiva del mexicano. Incluso ignoramos adónde ha ido a parar, si es que se conservó, la pintura original de aquel Santo Ecce Homo, que recibió culto, en una hornacina, sita en el Portal de Mercaderes de la Plaza Mayor de México (Figura 1). Fue en 1895, durante el gobierno de Porfirio Díaz (1877-1911), cuando los inmuebles de este sector suroeste del Zócalo, para esa fecha muy deteriorados y donde estaba el citado portal, se tiraron dando lugar a nuevas edificaciones como el Centro Mercantil y posteriormente el Gran Hotel de la Ciudad. Este extremo suroeste del Portal de Mercaderes, en esquina con la actual calle 16 de septiembre, también se conoció como de los Agustinos, ya que les fue cedido en 1673 para su explotación económica, arrendando el espacio a los comerciantes que allí quisieran poner sus puestos ambulantes de venta o "cajones". Así, una placa ovalada adosada a la pared recordaba esa cesión de este modo: "EL CONBENTO REAL DE SAN AGUSTÍN/ CUYO ES 


\section{ESTE PORTAL/ TIENE EJECUTORIA DEL SUPE/ RIOR GOBIERNO DE ESTA NUEVA ESPAÑA PARA/ Q. SE PUEDA PONER CAJÓN"²4.}

Además, iconográficamente no se trata de un Ecce Homo, sino de un Cristo de la Humildad o de la Paciencia, es decir, representa un momento muy distinto de la Pasión de Cristo, aunque sus devotos y fieles, que acudían a él en cualquier momento al estar en un espacio público abierto, lo denominaran por la primera iconografía, por ser la más difundida y reconocida a nivel popular.

Por eso, es oportuno, aclarar brevemente el significado de una y otra para justificar que se trata de un Cristo de la Humildad o Paciencia y no un Ecce Homo. Este último representa el momento en que Cristo, tras ser flagelado y vejado en su realeza divina, con un manto rojo, una corona de espinas y una caña, Pilatos lo muestra a las gentes para que, viéndolo tan lacerado, se apiadaran de él y así liberarlo, no lográndolo sino, al contrario, enervar aún más a la muchedumbre en su contra. Mientras el de la Humildad o de la Paciencia evoca los instantes previos a su crucifixión en el madero de la cruz. Es decir, cuando Cristo, ya en el Gólgota, sentado sobre una roca, volviendo el rostro hacia el espectador buscando su compasión y piedad, casi desnudo, pues solo le cubre el perizoma y con las piernas inclinadas o cruzadas, piensa y medita, ajeno al trajín que le envuelve, que su tragedia estaba acabando o, visto desde otra perspectiva, que su misión redentora, encomendada por el Padre a este mundo, estaba a punto de completarse.

No ha sido fácil, insistimos en ello, la identificación de la imagen origen y causante de este trampantojo granadino. Al principio creímos que podría tratarse del famoso Señor del Cacao de la catedral primada de México -idea compartida y ratificada por varios historiadores del arte mexicanos a los que acudimos en busca de consejo-. El Señor del Cacao -denominación popular, oficialmente Santo Cristo de la Humildad- es una sorprendente imagen de pasta de maíz, muy querida y venerada, es decir, algo similar a la vecina del Portal. Según Manuel Toussaint, originariamente estuvo en una hornacina del atrio catedralicio y en un platillo que le acompañaban se podía depositar granos de cacao para las obras de la catedral ${ }^{25}$, siendo durante el gobierno del arzobispo Pascual Díaz Barreto (1929-1936) cuando se pasó al interior de la catedral, concretamente a la capilla de San José -recientemente ha sido objeto de un brutal atentado, cuyos daños se han subsanados pronto y con acierto-. Esta iconografía, también a ambos lados del Atlántico conocida por el Sentaíllo y más aún por Cristo de la cañilla, por tenerla en la mano izquierda, tiene muy celebrados ejemplos en México, destacando los de las ciudades de Paztcuaro y Morelia -la antigua Valladolid-, ambas en el Estado de Michoacán.

Ha sido Carlos Arzáez Berzunza, investigador del Museo de la Basílica de Guadalupe, quien nos dio la pista para identificar el original mexicano aquí

\footnotetext{
${ }^{24}$ Suárez, 2002: 129.

25 Toussaint, 1992: 156.
} 
representado -a él mi gratitud-, al suministrarnos una estampa del desaparecido Santo Ecce Homo del Portal que se incluyó en una reedición tardía de la obra de fray Pedro Gómez Durán, Historia de la Vida de Cristo [...], publicada en Madrid en $1778^{26}$, pudiendo comprobar que las similitudes entre el cuadro granadino y el grabado novohispano son similares y lo que es aún clave, que al pie del grabado figura su nombre: El Santo Ecce Homo del Portal, por su ubicación, el Portal de Mercaderes de la Plaza Mayor de México, dato este último que no está en la pintura granadina, lo que nos ha obstaculizado aún más su identificación (Figura 2).

La Plaza Mayor de México, oficialmente de la Constitución -curiosamente por la de Cádiz de 1812-, y popularmente El Zócalo, ya desde su primitivo trazado por el alarife y geómetra Alonso García Bravo (1490-1561) por mandato de Hernán Cortés (1485-1547), ha sido y sigue siendo el centro urbano capitalino por excelencia, por lo que el comercio, las fiestas, las procesiones, las reuniones, etc., han tenido en su devenir histórico un papel clave y fundamental. Su amplia superficie - un gran rectángulo de casi 47.000 metros cuadrados- hoy totalmente despejada y libre, durante parte del virreinato acogió multitud de puestos ambulantes, tenderetes incluso un mercado de fábrica, el Parían, activo entre 1688 y 1844. Frente a él, conformando el costado suroeste de su perímetro se encontraba el Portal de Mercaderes $^{27}$, en realidad los soportales o galerías bajas, como es normal en los centros históricos, de una serie de grandes viviendas contiguas que iban desde la antigua calle Platería - hoy Francisco Madero- hasta la

${ }^{26}$ Gómez Durán, 1778: 2. Concretamente aparece en la parte posterior de la portada del libro, en realidad una reedición, siendo la edición prínceps de 1663, en Madrid, por Joseph Fernández de Buendía, que estuvo dedicada a don Andrés Villarán, caballero de la Orden de Santiago, del Consejo de Su Majestad y su secretario en el Real de Hazienda. Lo que nos avala la gran difusión que tuvo esta piadosa imagen, pues junto a esta edición del último tercio del Setecientos se hicieron otras dos. El mismo editor de 1778 ya hizo una edición anterior, concretamente en 1767, y, aún antes de acabar el siglo XVIII, hubo otra nueva edición de la obra, concretamente en 1791 por don Gerónimo Ortega e Hijos de Ibarra y a costa de la Real Compañía de Impresores y Libreros del Reino.

${ }^{27}$ Son varias las pinturas que sobre la Plaza Mayor de México de la época del virreinato nos han llegado a la actualidad. A modo de ejemplo señalaremos tres: la de Juan de Villalpando de 1695, la atribuida a Juan Antonio Prado hacia 1767 o la de Juan Patricio Morlete de 1770. En las tres queda evidenciada de manera palpable y clarividente la fecunda actividad festiva, social, comercial, etc., que se desarrollaba en este gran espacio público que era y sigue siendo el corazón de la Ciudad de México. Tanto la primera como la última de las vistas centran su objetivo en la catedral y en el palacio del virrey -hoy Palacio Nacional-, sus dos edificios más emblemáticos e importantes; solo la segunda, atribuida a Prado, donde se recoge la comitiva del nuevo virrey Carlos Francisco de Croix (17031778), que atraviesa la Plaza Mayor camino de la catedral en el día de su toma de posesión del cargo 25 de agosto de 1766, aparece como telón de fondo y, además, muy bien representado, el Portal de los Mercaderes. 
de 16 de Septiembre, en su último tramo -antes Tlapaleros-y a las que se accedía mediante robustas arcadas de medio punto sobre pilastras toscanas. En los comercios o tiendas abiertos a estos soportales, que ofrecían mayor seguridad, se podían encontrar productos de más calidad e incluso de importación, bien de la metrópoli o de Filipinas, sin olvidar que dentro de los mismos soportales se ponían a diario puestos ambulantes, a los que se llamaba cajones, porque las mercancías se exhibían sobre ellos como estudió Gabriela Sánchez Reyes ${ }^{28}$.

Precisamente, en la parte izquierda del Portal de Mercaderes había dos nichos, donde se alojaban dos devotas pinturas: el Santo Ecce Homo del Portal en uno y en el otro una Inmaculada Concepción. El historiador local Juan de Viera nos dejó una descripción preciosa y precisa de ambas pinturas y de sus hornacinas: "En el Portal de Mercaderes está un nicho con una hermosísima imagen de una antigua pintura de un Ecce Homo de dos varas y media [167 cm], bajo un cristal, en un marco de plata macizo, en cuya presencia arden todo el día muchas luces y está sobre una repisa que hace de sotobanco o altar de un fingido jaspe y adornado de diversas de ramilletes, así de plata como de metal y varios faroles donde le arden luces [...] de noche y día. Y al salir de este portal está otro nicho de la Inmaculada Concepción de Nuestra Señora bajo un cristal, cuya pintura es objeto de la mayor devoción. Tiene sus adornos, aunque no tan costosos y ricos como los del Ecce Homo..." 29 .

Como se deduce de este preciso texto, no fue un simple hueco abierto en el muro de una notable vivienda a fin de sacralizar un espacio público -en muchos casos hechos por el mismo dueño de la casa a fin publicitar sus devociones particulares-, sino que por sus proporciones se trataría de una profunda hornacina, casi una pequeña capilla callejera abierta, estando mejor amueblada la del Cristo, cuyo estado dolorido y resignado por la tragedia de su Pasión sobre todo en sus momentos finales, calaría más hondo en el alma del fiel creyente que la pintura amable y agradable de la Inmaculada.

$\mathrm{Su}$ fama de taumaturgo aumentó su popularidad y nombradía creciendo a la par las donaciones de aquellas gentes sencillas y humildes que a Él acudían en busca de consuelo y amparo. Incluso tal celebridad le llevaría a convertirse en un hito singular o punto de referencia de la vida urbana en otros aspectos ajenos a los rigurosamente devocionales, tales como anuncios de venta de casas, pérdidas

${ }^{28}$ Sánchez Reyes, 2007: 2-15.

${ }^{29}$ De Viera, 1778: 5. El manuscrito original se guarda en la Biblioteca Nacional de Francia: https://gallica.bnf.fr/ark:/12148/btv1b100329980. A lo largo del siglo XVIII, la ciudad de México sufrió profundas transformaciones en su estructura urbana. Ese interesante proceso de cambio quedó cabalmente reflejado en las crónicas de Agustín de Vetancurt, Juan Manuel de San Vicente y Juan de Viera. Dichos textos han sido objeto de numerosas publicaciones con prólogo, comentarios y corpus bibliográfico de distintos autores. Aquí señalaremos Rubial García, 1990: 190. 
de objetos de valor, etc. Así, en el primer caso, en 1784, la Gaceta de México anunciaba la venta de dos casas contiguas y nuevas, debiendo acudir los interesados en su compra al cajón - puesto o tienda- de Antonio Arnaldo, situado en el Portal de Mercaderes, junto al Santo Ecce Homo ${ }^{30}$. Y en el segundo caso tenemos que, en 1805, el Diario de México, tras anunciar la pérdida de una hebilla de oro, advertía que se gratificaría generosamente a quien la hubiere encontrado si la devolvía en la casa número 4 del Portal de Mercaderes, junto al Santo Ecce Homo ${ }^{31}$.

Por último, testimonio elocuente de la gran repercusión y admiración que en todo el territorio novohispano alcanzó la devoción y fervor al Santo Ecce Homo del Portal, es una encantadora pintura -óleo sobre lienzo- perteneciente al Museo del Virreinato del Tepotzotlán con el nombre genérico de Devocionario (Figura 3). De 180 x $120 \mathrm{~cm}$, es obra anónima, aunque en la parte inferior aparece la siguiente leyenda: "Se acabó el 24 de julio de 1827”. De relativo valor artístico, aunque sí histórico y devocional, nos relaciona y presenta, de forma sencilla y candorosa, las principales advocaciones de Cristo, de María y de aquellos santos que despertaban el fervor y la devoción de los fieles mexicanos. El lienzo se divide en tres calles y a su vez en cada una van superpuestas diversas casillas con una advocación concreta, en total 23, siendo, precisamente el Santo Ecce Homo del Portal el que ocupa el eje y centro de toda la composición, incluso sin estar debajo su nombre, como en casi todos los demás, prueba evidente de que su fama era tal que no necesitaba fijarla por escrito ${ }^{32}$.

Paralelamente, y como complemento, a este original y testimonial cuadro de una de las devociones más queridas y veneradas por los mexicanos, bien autóctonas o importadas desde España, estarían, sin duda, las copias para satisfacer la demanda de sus devotos. Estampas o grabados para los más humildes y con menos recursos económicos y pinturas para aquellos otros de más posibilidades -un

${ }^{30}$ Valdés Murgía y Saldaña, 1784: 311.

31 Bustamante Marecilla, 1805: 144.

32 En total son 23 imágenes las representadas, empezando por la Santísima Trinidad. Dentro de las cristológicas tenemos la Eucaristía, mediante una custodia de sol, el Santo Ecce Homo del Portal, Jesús Preso y el Buen Pastor, en la parte inferior flanqueado por el Crucificado de Santa Teresa y el de Chalma. Dentro de las marianas: la Inmaculada, la Asunción, la Virgen del Rosario, la Soledad, la Virgen de la Luz, Nuestra Señora de Ocotlán (las dos últimas muy mexicanas), la del Socorro y la de Cueva Santa (de origen levantino, pues procede de Altura en Castellón); por fin, el santoral es el más representado, la mayoría son santos muy conocidos como San Antonio, San Vicente Ferrer, San José, San Juan de Dios, San Cayetano o San Jerónimo y otros menos venerados en España como San Camilo y sobre todo San Caralampio. Agradecemos a don César Augusto Jiménez Ramírez, conocedor del tema, la información facilitada, incluido el enlace de los fondos del Instituto Nacional de Antropología e Historia para llegar a la ficha técnica de esta pintura, que es el siguiente: http://mediateca.inah.gob.mx/islandora_74/islandora/object/pintura $\% 3 \mathrm{~A} 2679$. 
trampantojo-, aunque tanto en un caso como en otro, el interés artístico no importaba mucho, siendo la copia granadina una excepción al ir fechada y firmado por Antonio de Torres. Además, aunque el tema está en ciernes, esta copia debe ser una de las más notables realizadas al Santo Ecce Homo del Portal de México y acaso el único ejemplo conocido hasta ahora en España (Figura 4). Aunque advertiremos que en Osuna recibe culto un Cristo de la Humildad, conocido también como de la Caña, Jesús Cautivo o el Santo Ecce Homo del Portal, por lo que pudo tener su principio en el mexicano. Pertenece a la cofradía de la Vera-Cruz, en origen sita canónicamente en el convento de San Francisco, como es norma en la Vera-Cruz, pasando después a la iglesia de San Agustín ${ }^{33}$. La imagen es una gran talla atribuida por José Luis Romero de Torres a Fernando Ortiz, escultor malagueño del Setecientos ${ }^{34}$.

\section{EL CUADRO DEL SANTO ECCE HOMO DEL PORTAL DE GRANADA}

No podemos ofrecer un estudio de detalle de esta pintura, firmada y fechada en 1726 (Figura 5) pues, aunque se conserva bastante bien, la falta de una limpieza no nos permite valorar sus pormenores, sobre todo su colorido. A priori, por sus medidas $(213 \times 145 \mathrm{~cm})$, tal vez excesivas para ser una copia de una imagen devocional, se podría tratar de una obra pensada en origen para ocupar el retablo de una capilla. Además, aquí y ahora, tampoco Antonio de Torres nos ofrece una idea cabal y completa de cómo sería aquella hornacina del Portal de Mercaderes de México, donde se veneró durante más de dos siglos, pues ni se recrea en su estructura física ni en sus detalles decorativos, como lámparas, floreros, etc., que, con tanto primor, nos informa el texto de Juan de Viera de 1778, y que Torres, en cambio, sí detalla en otros casos parecidos. Recordemos la copia del Nazareno del Hospital de su nombre y de la Concepción de Ciudad de México, sita en el convento de carmelitas descalzas de Antequera ${ }^{35}$, pues aquí su objetivo es la venerada imagen del Santo Ecce Homo del Portal.

Así, sobre ese fingido altar de jaspe, cubierto por un paño, cuyas ricas puntillas de encaje se expanden por su frente, centra la escena la noble figura de

${ }^{33}$ Rodríguez-Buzón Calle, 1986: 109-115.

${ }^{34}$ Romero Torres, 2017: 264-268. Incluso figuró en la gran exposición que el Obispado de Málaga le dedicó a este artista malagueño hace dos años, comisariada por el mismo Romero Torres.

${ }^{35}$ Recientemente ha aparecido otra copia anónima en el seminario de San Carlos Borromeo de la ciudad de Wynnewood (Pensilvania). De $96 \times 71 \mathrm{~cm}$, ha sido dado a conocer por Robin, 2015: 157-171. Incluso en Chiclana de la Frontera en Cádiz existe un convento de agustinas recoletas, fundado en 1666, bajo la advocación de este Jesús Nazareno de origen mexicano, popularmente conocido como El Divino Indiano. Alonso de la Sierra et alii, 2005: 16-18. 
Cristo, no de frente, sino algo escorado hacia la izquierda. Sentado sobre un sobrio cajón rectangular, consciente de que está ya en el preámbulo de su crucifixión o lo que es lo mismo en el momento culminante de su total humillación, avanza ligeramente la pierna izquierda apoyando sobre ella el mismo brazo en cuya mano porta una cañilla. En un elaborado contraposto, retrocede la pierna derecha, apoya en la rodilla su brazo, abriendo su mano para reposar la cabeza, que gira levemente hacia el fiel creyente para mostrarnos su afligido y apenado rostro, pero sin estridencias ni aspavientos, con una mirada tierna y penetrante, mas ni incisiva ni hiriente, sino benevolente e indulgente, buscando la compasión y el sentimiento de aflicción de sus devotos. Gran dibujante, Torres perfila la figura de Cristo con unos matices delicados y a la vez contundentes. No incide en lo negativo de la Pasión, pues solo le coloca la corona de espinas y la soga, que al estar sentado descansa sobre el cajón donde se asienta, en la que también se expande su amplio paño de pureza.

Finalmente, advertir que para darle ese carácter de trampantojo teatral, en un primer plano, a modo de escenario, enmarcan la escena una bambalina, mientras el telón, partido por la mitad en dos hojas, con elegantes y armónicos pliegues recogidos a los lados, nos dejan ver en el centro la noble figura de Cristo expectante ante su crucifixión, de un fuerte acento escultórico, a pesar de que el original novohispano era una pintura.

\section{LA DORMICIÓN DE LA VIRGEN DEL SEMINARIO DE LOS SACERDOTES OPERARIOS DIOCESANOS DE CIUDAD DE MÉXICO}

Si la pintura del Santo Ecce Homo pertenece cronológicamente a su segunda etapa profesional, la que ahora abordamos, firmada y fechada en 1713, es de la primera, que fijamos entre 1703 y 1722 (Figuras 6 y 7). Por lo tanto pertenece al momento álgido de su carrera artística, aunque no hay mucha obra de estas fechas, firmada y datada. De 140 x $190 \mathrm{~cm}$, es decir, de formato apaisado, se halla en la capilla del Seminario Mayor Mosén Sol, de la hermandad de Sacerdotes Operarios Diocesanos, quienes nos han dado todo tipo de datos e información ${ }^{36}$.

El Tránsito o la Dormición de la Virgen María, cuando culmina su vida terrenal y está a punto de ser llevada a los cielos -la Asunción-, es un motivo básico dentro de la iconografía mariana, tanto en escultura como en pintura, bien tratado aisladamente - al ser la titular del gremio vinculado con la edilicia, fue el asunto principal para sus capillas corporativas-, como dentro de las grandes series marianas para retablos u otro lugares conventuales o parroquiales. Además

${ }^{36}$ Agradecemos al padre José Roberto Ávila Rangel, de la comunidad de Sacerdotes Operarios Diocesanos de Ciudad de México, la confianza depositada en mi persona para que llevara a cabo el estudio y publicación de esta hermosa pintura. 
de todos los episodios memorables de la vida de la Virgen que conforman las series marianas, es sin duda el que casi nunca se omite, a pesar de su gran complejidad iconográfica, pues María aparece yacente sobre su lecho y rodeada de los apóstoles, por lo que solucionar y adaptar armónicamente tanta figura o personaje en torno a la Virgen es tarea ardua y difícil y en consecuencia, en muchas ocasiones no todos los artistas solventan el tema con gracia y soltura, aunque, sin duda, en este caso las obras de pintores más antiguos en el tiempo sirven de fuente de inspiración a los más jóvenes, junto a las tradicionales fuentes gráficas.

Ignoramos si esta pintura, que hoy aparece sola, en origen formó parte de una serie mariana. Sea como fuere, lo cierto es que por su fecha, 1713, supone el primer ejemplo conocido donde Antonio de Torres abordó este especial momento de la vida de María y además con gran fortuna, acierto y originalidad. Pues, aunque el tema ya había sido tratado en varias ocasiones por artistas algo anteriores a él como Villalpando o Correa, Antonio de Torres, tras numerosos estudios y bocetos previos, elaboró una obra bastante original, aunque evidentemente sin olvidar deudas con fuentes grabadas o pinturas. En el primero de los casos los dos angelitos que, rebosando gracia y donaire revolotean en una vaporosa nube superior con ramos de flores, dejando caer algunas sobre el cuerpo de la Virgen y todo el habitáculo (Figura 8), aparecen de igual modo en los grabados dedicados a la Fe y a la Caridad de Jan Pietersz Saenredan de 1601 sobre composición de H. Goltzius ${ }^{37}$. También el lecho donde yace María es muy similar al de la obra del mismo tema de Juan Correa, hoy en el Arzobispado de México ${ }^{38}$.

Dentro de una gran admiración y devoción de los apóstoles hacia María, la escena tiene por eje un amplio lecho, donde ella yace, resuelto en diagonal, lo que le da gran originalidad y profundidad. Cubierta con un amplio paño rosáceo, en realidad un tul que forma una delicada transparencia, su grácil figura, con túnica blanca, manto azul como es preceptivo, y corona de flores sobre su cabeza, no posa una mano sobre la otra, como es norma en estas composiciones, sino que une sus manos en actitud de oración, recordándonos que duerme y no ha muerto. A su izquierda cuatro apóstoles, tres de rodillas y uno de pie al fondo mirando a los angelitos que, desde la gloria, vierten flores sobre la Virgen María y el primero San Pedro, con túnica azul y manto marrón, con gozo y júbilo se lleva las manos al pecho como admiración. En el lado opuesto y de forma escalonada los ocho apóstoles restantes, los primeros de rodillas, destacando San Juan con manto verde, los más lejanos de pie, generalmente con las manos abiertas como gesto de admiración ante la figura de María, que no ha muerto sino que descansa sobre blancos almohadones en una cama cubierta de flores, que caen desde arriba

\footnotetext{
${ }^{37}$ Navarrete Prieto, 1998: 140.

${ }^{38}$ La imagen y la información pertenecen a don Alejandro Hernández, profesor de la Universidad Iberoamericana de Ciudad de México.
} 
y tapizan el suelo con sus ricos colores; por fin, abajo y en el centro, la firma y la fecha de Antonio de Torres.

Finalmente, advertir que esta es la primera ocasión documentada en que Antonio de Torres abordó este tema mariano y además con gran fortuna y acierto; después entre 1719 y 1720 lo afrontó de nuevo. Fue en la gran serie mariana del museo del antiguo convento franciscano de Guadalupe-Zacatecas, formada hoy por catorce pinturas, en origen era una más, que fue robada en la ya lejana fecha de 1935.

Fecha de recepción: 30 de octubre de 2019

Fecha de aceptación: 23 de febrero de 2020

\section{BIBLIOGRAFÍA}

Álvarez García, José Javier (2004): "La muralla islámica del monasterio de la Encarnación de Granada”. En: Anuario Arqueológico de Andalucía, I, pp. 1403-1414.

Alonso de la Sierra, Juan et alii (2005): Guía artística de Cádiz y su provincia II. Cádiz: Diputación de Cádiz/Fundación José Manuel Lara.

Barea Azcón, Patricia (2007): "Iconografía de la Virgen de Guadalupe de México en Granada”. En: Cuadernos de Arte de la Universidad de Granada, 38, pp. 379-381.

Barrios Rozúa, Juan Manuel (1998): Reforma urbana y destrucción del patrimonio histórico de Granada. Granada: Universidad de Granada/Junta de Andalucía.

Bustamante y Marecilla, Antonio Manuel (1805): Diario de México. Dedicado al Excmo. Sr. D. José de Yturrigaray, Caballero Profeso de la Orden de Santiago. Teniente General de los Reales Ejércitos, Virrey, Gobernador, Capitán General de la Nueva España y Presidente de su Real Audiencia. México: D. José Antonio de Hogal, Impresor de Palacio, tomo I.

Clavijo García, Agustín (1984): "Pintura colonial en Málaga y su provincia". En: Actas de las IV Jornadas de Andalucía y América. Huelva: Universidad Internacional de Andalucía, vol. II, pp. 98-99.

De la Chica Benavides, Fray Juan (1764): Gazetilla curiosa o semanero granadino, noticioso y útil para el bien común. Granada: Imprenta de la Santísima Trinidad.

De Viera, Juan (1778): Breve compendiosa narración de la Ciudad de México. Corte y Cabeza de toda la América Septentrional. Que a instancias de un amigo bosquejó el presbítero de este Arzobispado y mayordomo de las rentas del Real y más Antiguo Colegio de San Pedro, San Pablo y San Ildefonso y las de su anexo que era el Real de Christo, natural de la ciudad de los Ángeles. Ms. de la Biblioteca Nacional de Francia. https://gallica.bnf.fr/ark:/12148/btv1b100329980. 
Gila Medina, Lázaro (2015): “Aproximación a la vida y obra del pintor novohispano Antonio de Torres (1667-1731) y estudio de una serie mariana inédita del convento de la Encarnación de Granada". En: Anales del Museo de América, XXI, pp. 82-113.

Gallego y Burín, Antonio (1996): Granada. Guía artística e histórica de la ciudad. Granada: Comares.

Gómez Durán, Fray Pedro (1778): Historia Universal de la vida y peregrinación del Hijo de Dios en el mundo: Muerte, Pasión y Resurrección de Christo, Redentor y Señor nuestro, con toda la descripción de la Tierra Santa de Jerusalén. Por Pedro [...], Freyle del Hábito de Santiago, y Profeso en la Casa de León. Madrid: Joachín de Ibarra, Impresor de Cámara de S. M.

Gómez-Moreno González, Manuel (1892): Guía de Granada. Granada: Imprenta de Indalecio Ventura.

López Rodríguez, Miguel Ángel (1993): Los arzobispos de Granada. Retratos y semblanzas. Granada: Arzobispado de Granada.

Lozada León, Guadalupe (2016): "Vendimia en la Plaza Mayor. Una historia que va desde los primeros años de la Colonia hasta el siglo XIX”. En: Relatos e historia de México, IX. México: Editorial Raíces, pp. 16-23.

Navarrete Prieto, Benito (1998): La pintura andaluza del siglo XVII y sus fuentes grabadas. Madrid: Fundación de apoyo a la Historia del Arte Hispánico.

Obregón y Pérez Siliceo, Gonzalo (1992): Breve y compendiosa narración de la Ciudad de México de J. de Viera. México: Instituto "José María Luis Mora" de Investigaciones Históricas.

Pérez Sánchez, Alfonso E. (1992): “Trampantojo a lo divino”. En: Ephialte. Lecturas de Historia del Arte, III, pp. 139-155.

Ramírez Montes, Mina (1988): "El testamento del pintor Antonio de Torres". En: Anales del Instituto de Investigaciones Estéticas, 59, pp. 265-272.

Robin, Elena (2015): "Trampantojo a lo divino: El Nazareno del Hospital de Jesús en Pensilvania”. En: Anales del Instituto de Investigaciones Estéticas, 107, pp. 157-171.

Rodríguez-Buzón Calle, Manuel (1986): Guía artística de Osuna. Osuna: Patronato de Arte.

Romero Benítez, Jesús (1989): Guía artística de Antequera. Antequera: Caja de Ahorros de Antequera.

(2012): Antequera. Ciudad monumental. Antequera: Chapitel, Conservación y Restauración.

Romero Torres, José Luis (2017): Fernando Ortiz. Un escultor malagueño del siglo XVIII. Osuna: Patronato de Arte/Amigos de los Museos.

Rubial García, Antonio (1990): La Ciudad de México en el siglo XVIII (16901780). Tres crónicas: Agustín de Ventancurt, Juan Manuel de San Vicente y Juan Viera. México: CONACULTA (Consejo Nacional para la Cultura y las Artes). 
Ruiz Gomar, José Rogelio (1983): “El pintor Antonio Rodríguez y tres cuadros desconocidos". En: Anales del Instituto de Investigaciones Estéticas, 51, pp. 25-36.

(1989): "Noticias en torno al pintor Antonio de Torres en el archivo del Sagrario Metropolitano". En: Anales del Instituto de Investigaciones Estéticas, 60, pp. 222-224.

Sánchez Reyes, Gabriela (2007): “Tiendas, puestos y cajones en el Portal de Mercaderes de la Ciudad de México". En: Boletín de Monumentos Históricos, 9, pp. 2-15.

Sescosse, Federico (1993): El Colegio de Guadalupe de Zacatecas. Escuela de misioneros y semillero de mártires (1706-1793). México: Grupo FinancieroFondo Cultural Bancen.

Suárez, Isabel (2002): Leyendas de la Provincia de México. Zona Centro. México: Selector.

Suárez Molina, María Teresa (2009): "Los mercados de la ciudad de México y sus pinturas". En: Caminos y mercados de México. México: Universidad Nacional Autónoma de México-Instituto de Investigaciones Históricas e Instituto Nacional de Antropología e Historia, pp. 435-457. http://www.historicas. unam.mx/publicaciones/publicadigital/libros/caminosymercados/mercados. html (16-7-2019).

Toussaint, Manuel (1990): Pintura colonial en México. México: Universidad Nacional Autónoma-Instituto de Investigaciones Estéticas. (1992): La Catedral de México. México: Editorial Porrúa.

Tovar de Teresa, Guillermo (1997): Repertorio de artistas mexicanos. México: Grupo Financiero Bancomer, vol. III.

Valdés Murgía y Saldaña, Antonio Manuel (1784): Gazeta de México: Dedicada al Excmo. Sr. D. José de Yturrigaray. Caballero de la Orden de Santiago. Teniente General de los Reales Ejércitos, Virrey, Gobernador, Capitán General de la Nueva España y Presidente de su Real Audiencia I. México: José Antonio de Hogal, Impresor de Palacio. 


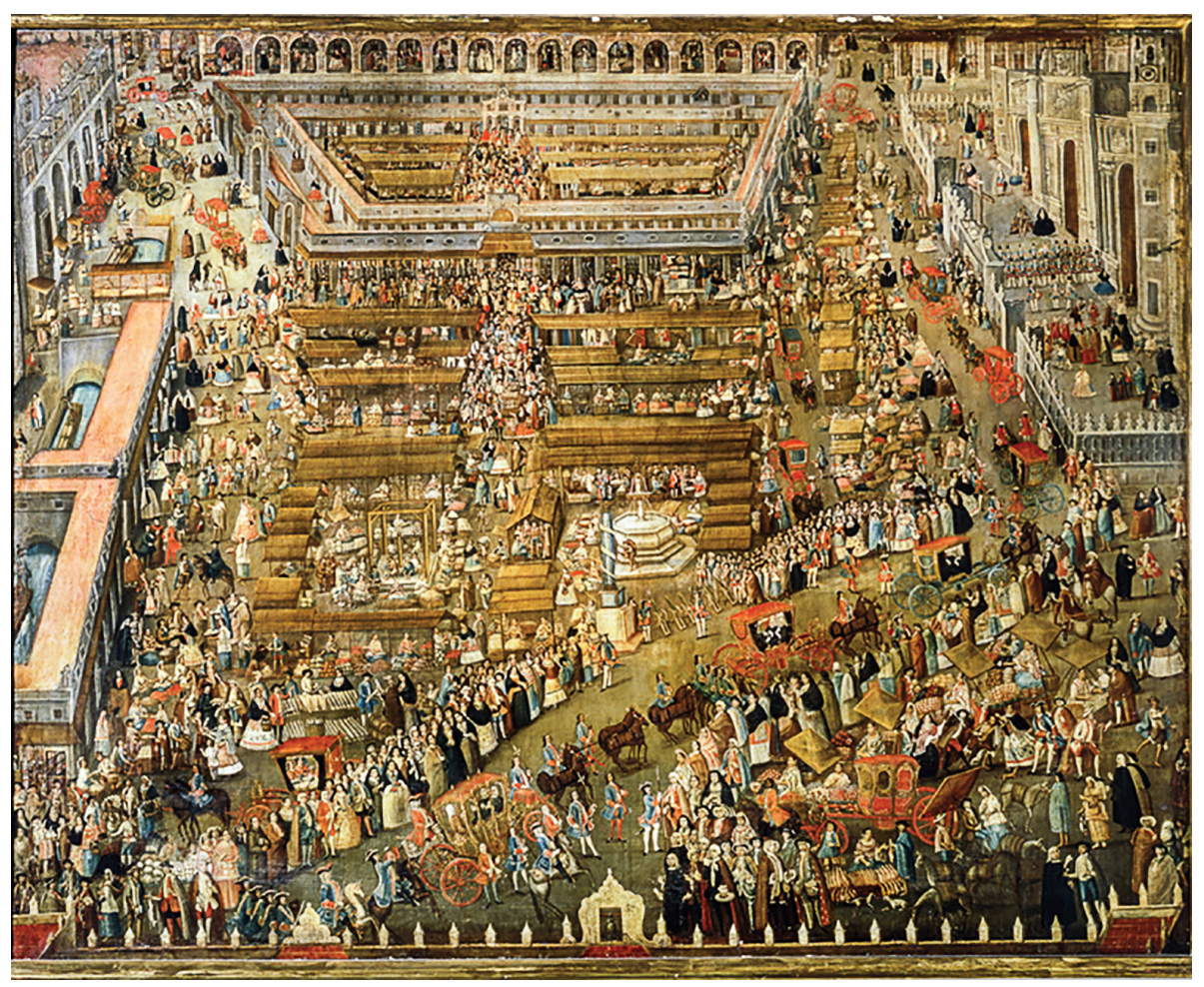

Figura 1. J. A. Prado (atribución), Plaza Mayor de México (al fondo el Portal de los Mercaderes), hacia 1767, Museo Nacional de Historia. Foto: gentileza de la Dra. Elisa García Barragán. 


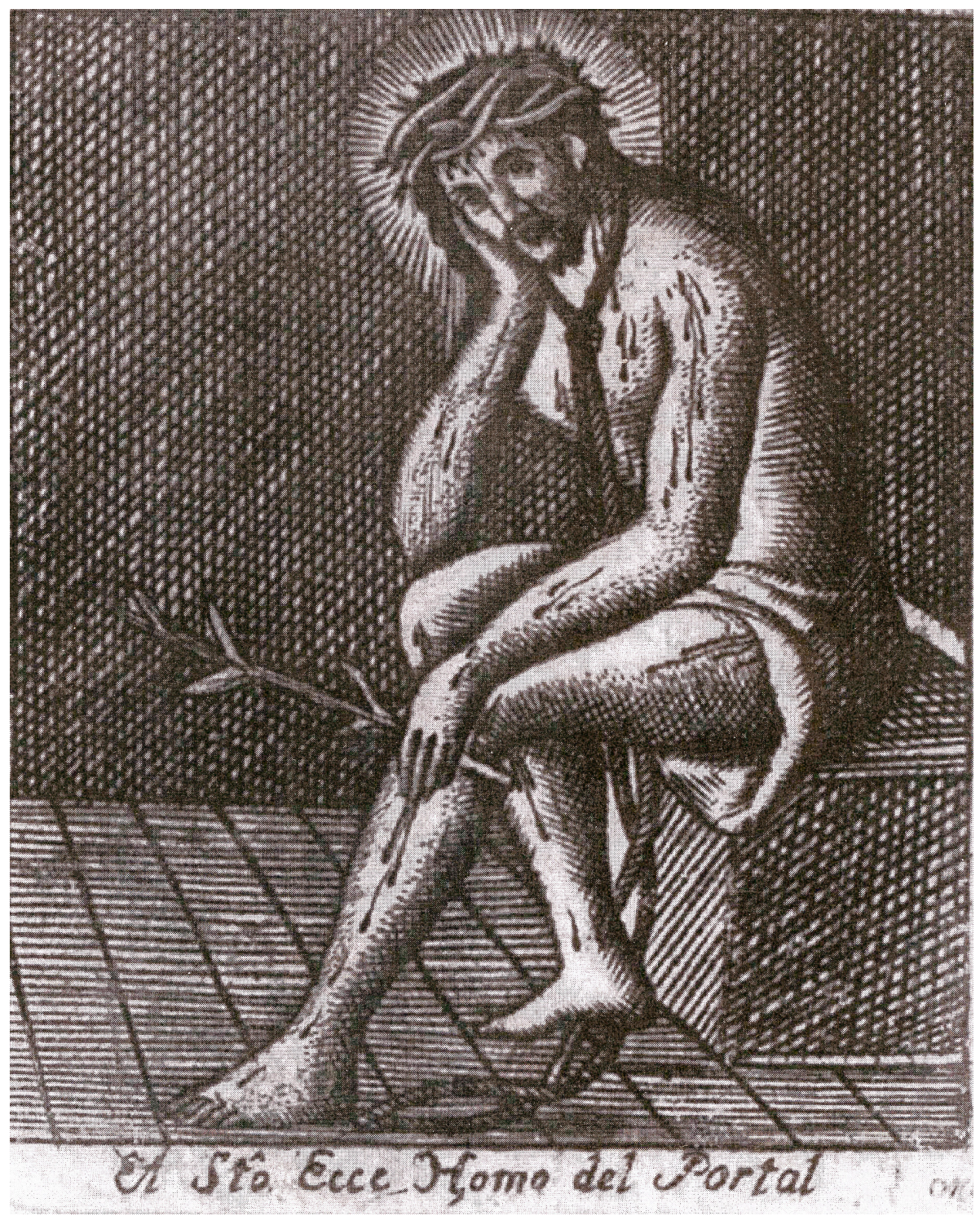

Figura 2. Santo Ecce Homo del Portal, grabado inserto en Gómez Durán, 1778.

LABORATORIO DE ARTE 32 (2020), pp. 207-230, ISSN 1130-5762

e-ISSN 2253-8305 - DOI http://dx.doi.org/10.12795/LA.2020.i32.11 


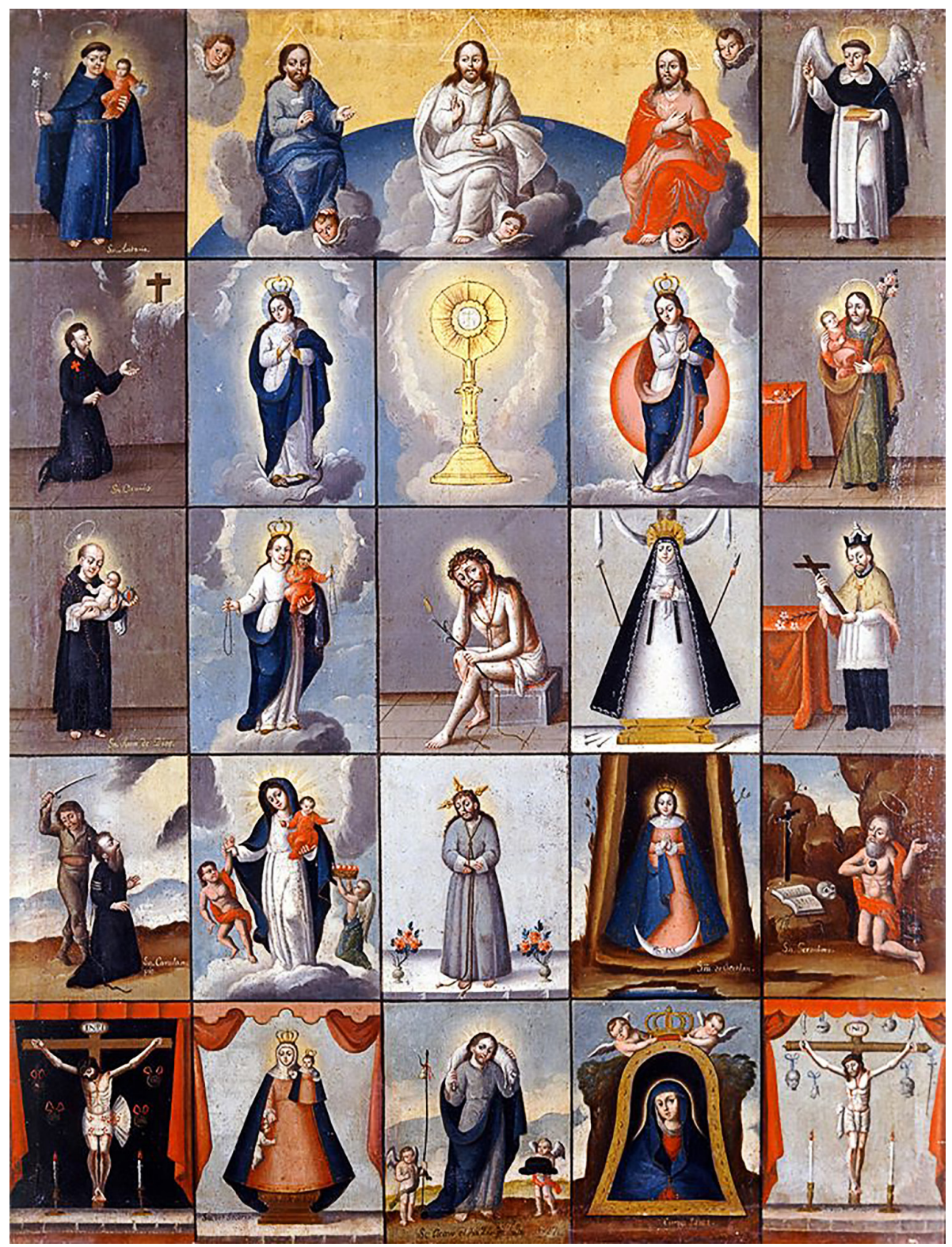

Figura 3. Anónimo, Devocionario mexicano, 1827, Museo Nacional del Virreinato. Foto: gentileza de César Augusto Ramírez Jiménez. 


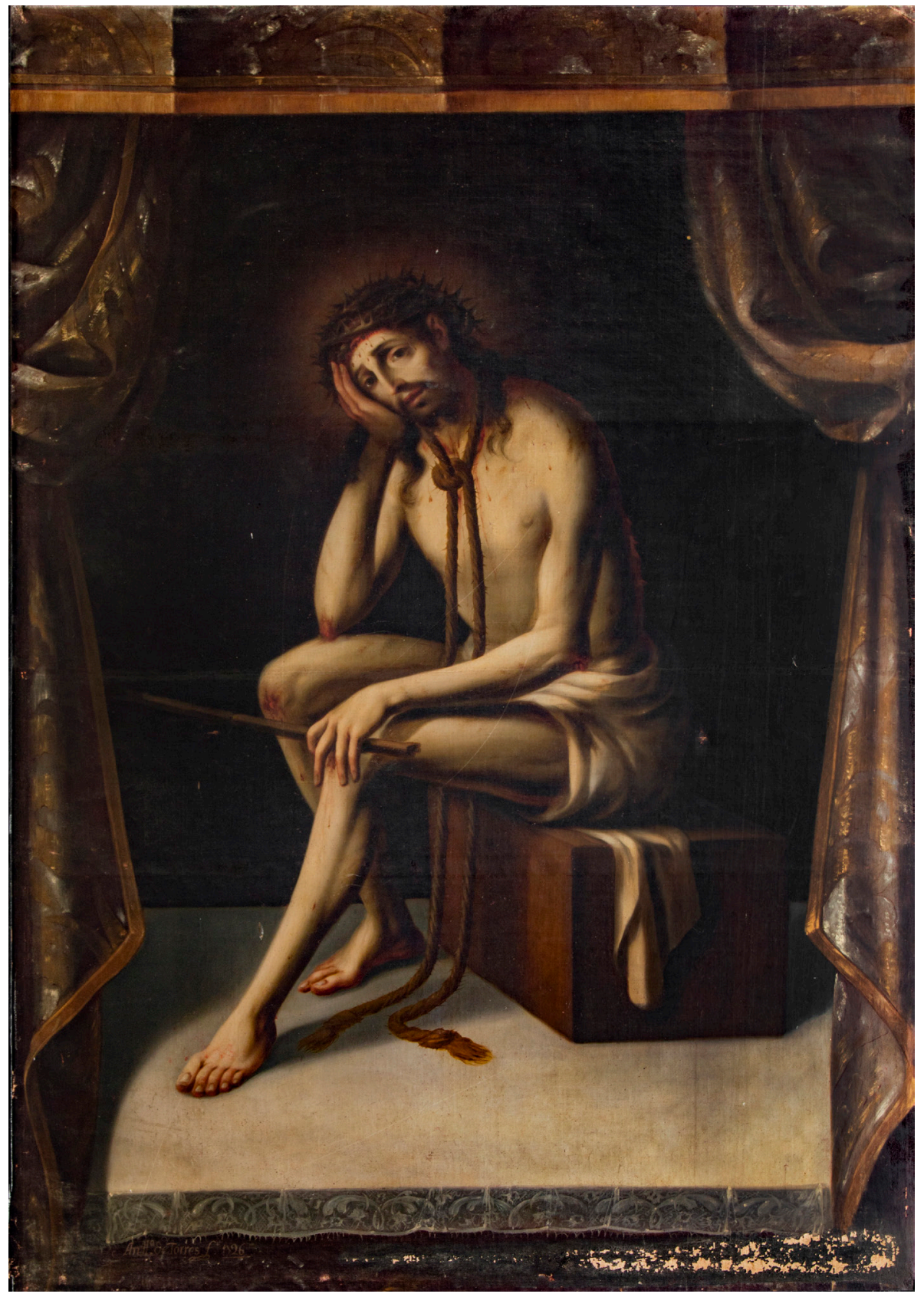

Figura 4. Antonio de Torres, Santo Ecce Homo del Portal, 1726, convento de la Encarnación de clarisas franciscanas de Granada. Foto: J. C. Madero López. 


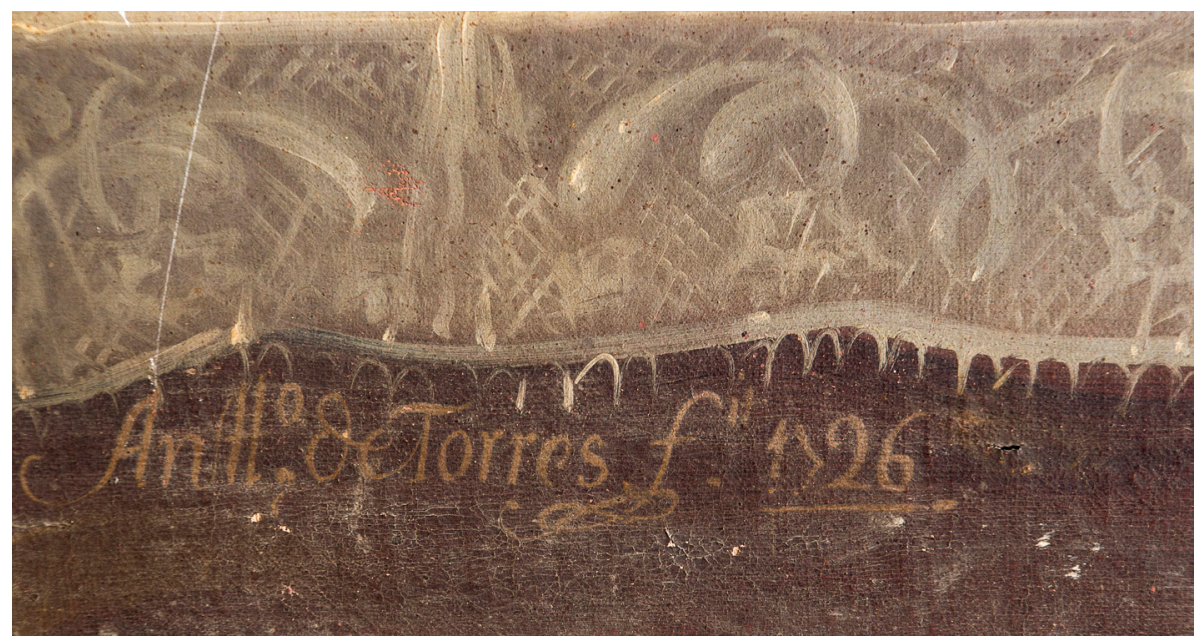

Figura 5. Antonio de Torres, Santo Ecce Homo del Portal (detalle de la fecha y firma del pintor), convento de la Encarnación de clarisas franciscanas de Granada. Foto: J. C. Madero López.

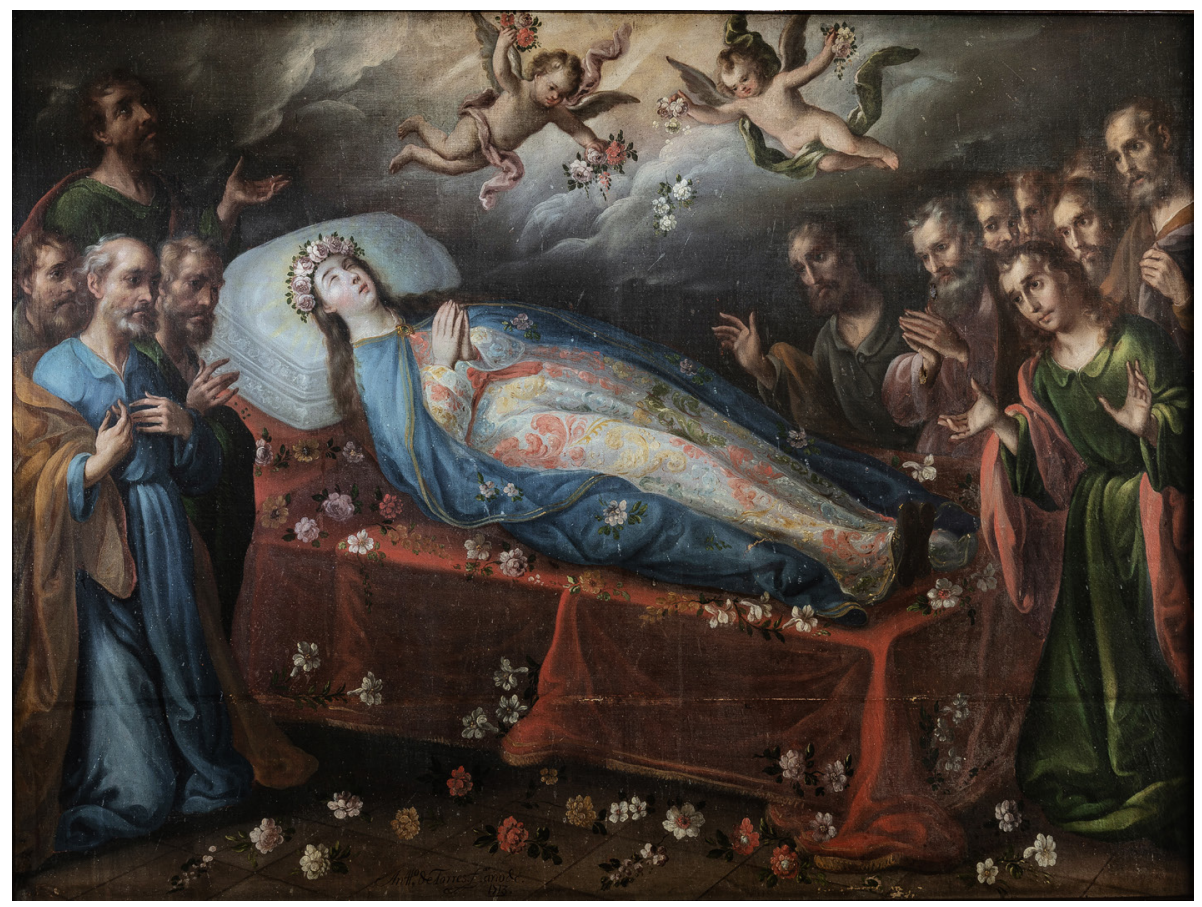

Figura 6. Antonio de Torres, Dormición de la Virgen, 1713, Seminario de Sacerdotes Operarios Diocesanos, México. Foto: Cintra Alejandra Segovia. 


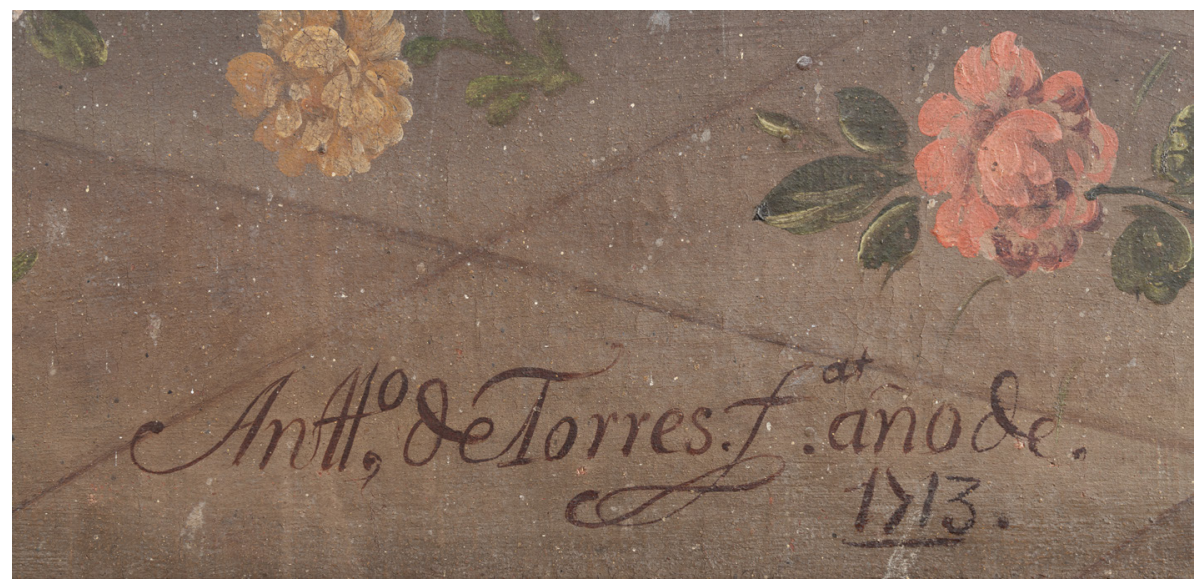

Figura 7. Antonio de Torres, Dormición de la Virgen (detalle de la fecha y firma del pintor), Seminario de Sacerdotes Operarios Diocesanos, México.

Foto: Cintra Alejandra Segovia.

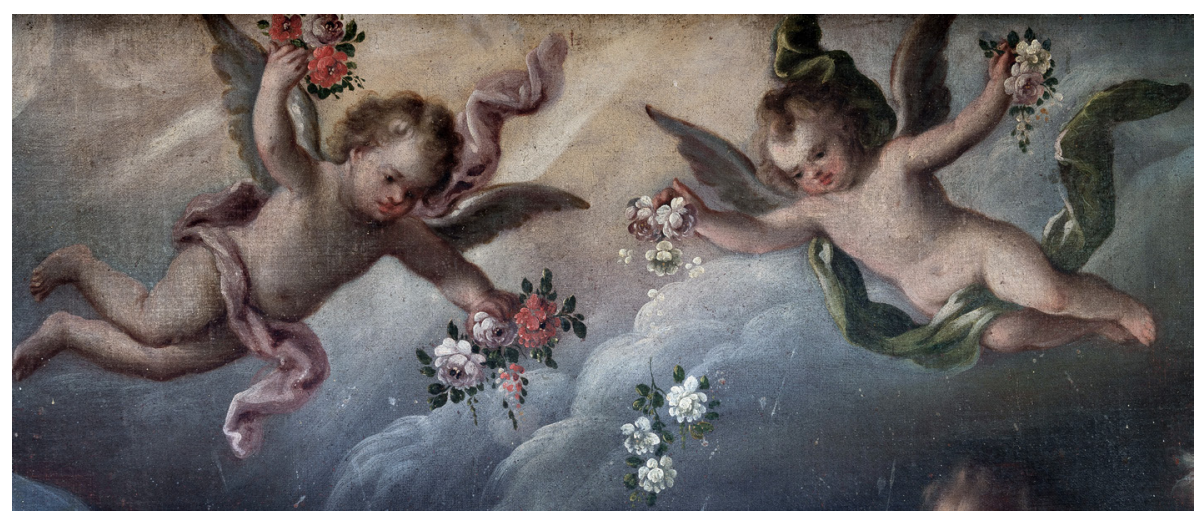

Figura 8. Antonio de Torres, Dormición de la Virgen (detalle de los ángeles echando flores a la Virgen María), Seminario de Sacerdotes Operarios Diocesanos, México. Foto: Cintra Alejandra Segovia. 